\title{
Impacts of Air Pollution on Productivity Growth in the Air and Truck Transportation Industries in the US: an Application of the Data Envelopment Analysis Malmquist Environmental Productivity Index
}

\author{
Jaesung Choi ${ }^{*}$, David C. Roberts ${ }^{2}$ \\ ${ }^{1}$ Transportation and Logistics Program, North Dakota State University, Fargo, ND, USA \\ ${ }^{2}$ Department of Agribusiness \& Applied Economics, North Dakota State University, Fargo, ND, USA \\ Email: jaesung.choi@ndsu.edu, david.c.roberts@ndsu.edu
}

Received 18 January 2015; accepted 7 February 2015; published 11 February 2015

Copyright (C) 2015 by authors and Scientific Research Publishing Inc.

This work is licensed under the Creative Commons Attribution International License (CC BY). http://creativecommons.org/licenses/by/4.0/

\section{(c) (i) Open Access}

\begin{abstract}
Air pollution worsens work environment and increases the likelihood of health risks and even premature death for humans. Owing to the fundamental structure of growth through the combustion of fossil fuels, productivity growth in the transportation industry has affected the natural environment. In this study, the authors use the Malmquist environmental productivity index to consider the effects of air pollution on productivity growth in the air and truck transportation industries, which are the biggest air polluters in the US. This study finds that on average, the air transportation industry does not increase actual productivity with an air pollution reduction, but the truck transportation industry positively grows with a reduction in one of the air pollutants studied (carbon monoxide, particulate matter) or both from 2008 to 2011, suggesting entering a period of environmentally sustainable transportation industry growth.
\end{abstract}

\section{Keywords}

Date Envelopment Analysis, Malmquist Environmental Productivity Index, Sustainable Growth, Air and Truck Transportation Industries

\section{Introduction}

The positive relationship between air pollution and the development of the transportation industry has led to

${ }^{*}$ Corresponding author.

How to cite this paper: Choi, J. and Roberts, D.C. (2015) Impacts of Air Pollution on Productivity Growth in the Air and Truck Transportation Industries in the US: an Application of the Data Envelopment Analysis Malmquist Environmental Productivity Index. Open Journal of Social Sciences, 3, 120-129. http://dx.doi.org/10.4236/jss.2015.32016 
many concerns for human health and the ecosystem since the 1997 Kyoto Protocol. The transport sector, which has usually operated by fossil fuel combustion for the past couple of centuries, has been a fundamental part of the economic growth of a nation [1]; on the other hand, transportation-made air pollutants such as lead, mercury, ozone, carbon monoxide (CO), and particulate matter (PM) have contributed to negative environmental changes (natural disasters, climate change, and global warming) and wellness issues in terms of respiratory sickness and even premature death [2] [3].

In 2011, the US Environmental Protection Agency, through surveys of willingness to pay for avoiding air pollution health risks, estimated that the benefits and costs of clean air would be $\$ 2$ trillion and $\$ 66$ billion per year from 1990 to 2020, respectively. They concluded that this is a result of increased productivity and decreased health expenses from a clean air environment [4]. Then, can we measure transportation productivity by incorporating the effects of air pollution which are not quantified? For the past few decades, conventional Malmquist productivity, which has been applied to a variety of fields to measure productivity change, has been developed by Färe et al. [5]-[7] and Färe and Grosskopf [8]. Conventional Malmquist productivity in an outputor input-oriented way uses non-environmental factors for inputs such as fuel, land, labor, and transport modes, but does not consider undesirable environmental factors such as air pollutants.

By contrast, a strong clean air environment has been considered to have an important impact on productivity growth. In fact, as early as 1980, Meyer and Gomez-Ibanez [9] mentioned that transportation modes that generate less pollution and use less energy must be more intensively used, and Gordon [10] suggested that it is desirable to include unmeasured changes in the quality of output caused by noise and pollution. Following Ball et al. [11], the Malmquist environmental productivity index was developed as the ratio of environmentally sensitive and conventional Malmquist productivities to explain the effects of environmental pollution on productivity growth. Managi et al. [12], Managi [13], Emilio [14], and Heng et al. [15] then applied it in a variety of fields including transportation. Managi et al. [12] measured oil and gas productivity for water pollution and oil spills from environmentally sensitive Malmquist productivity, while Managi [13] used it as an explanatory variable in his econometric model in order to test whether there is increasing returns to pollution abatement in the US agricultural sector. In 2010, the study of exporting and environmental performance by Emilio [14] utilized the Malmquist environmental productivity index to determine productivity heterogeneity and find out the differences in resource efficiency between export and non-export firms for environmental performance in the Spanish food industry. Similarly, Heng et al. [15] applied it to the US truck transportation industry to measure true productivity growth from a change in toxic air pollutants.

Transportation industries in the US have significantly contributed to air pollution, which negatively affects their productivities; it is thus desirable that the measurement of transportation productivity considers the effect of air pollution. To our best knowledge, few research studies have evaluated the air pollution effect on US transportation productivity at the state level in the two major polluting transportation industries. To address this limitation, the major objectives of this study are 1) to use the Malmquist environmental productivity index to examine if the US air and truck transportation industries show environmentally sustainable growth (air pollution reduction and productivity growth) by state and 2) to provide state policy planners and administrators with detailed state-level changes in productivity and air pollution in order to help them plan transportation air pollution regulations. The remainder of this study is as follows. Section 2 explains the methodology and Section 3 describes the data. In Sections 4 and 5, discussion and the results of the empirical analysis are shown and Section 6 concludes the study.

\section{Methodology}

Let us define:

$\mathrm{x}^{\mathrm{t}}=$ Input vector from time period, $\mathrm{t}=1, \ldots, \mathrm{T}$.

$\mathrm{b}^{\mathrm{t}}=$ Environmental pollution vector from time period, $\mathrm{t}=1, \ldots, \mathrm{T}$.

$\mathrm{y}^{\mathrm{t}}=$ Output vector from time period, $\mathrm{t}=1, \ldots, \mathrm{T}$.

$\mathrm{D}_{0}^{\mathrm{t}}\left(\mathrm{x}^{\mathrm{t}}, \mathrm{y}^{\mathrm{t}}, \mathrm{b}^{\mathrm{t}}\right)=$ Output distance function for the maximum change in outputs using a set of given $\mathrm{t}$ inputs with the technology at $t$.

$\mathrm{D}_{0}^{\mathrm{t}}\left(\mathrm{x}^{\mathrm{t}+1}, \mathrm{y}^{\mathrm{t}+1}, \mathrm{~b}^{\mathrm{t}+1}\right)=$ Output distance function for the maximum change in outputs using a set of given $\mathrm{t}+1$ inputs with the technology at $t$.

$\mathrm{D}_{0}^{\mathrm{t}+1}\left(\mathrm{x}^{\mathrm{t}}, \mathrm{y}^{\mathrm{t}}, \mathrm{b}^{\mathrm{t}}\right)=$ Output distance function for the maximum change in outputs using a set of given $\mathrm{t}$ inputs with the technology at $t+1$. 
$\mathrm{D}_{0}^{\mathrm{t}+1}\left(\mathrm{x}^{\mathrm{t}+1}, \mathrm{y}^{\mathrm{t}+1}, \mathrm{~b}^{\mathrm{t}+1}\right)=$ Output distance function for the maximum change in outputs using a set of given $\mathrm{t}+$ 1 inputs with the technology at $\mathrm{t}+1$.

Following Färe et al. [5]-[7] and Färe and Grosskopf [1], output-based conventional Malmquist productivity is defined as follows:

$$
M_{H}\left(x^{t+1}, y^{t+1}, x^{t}, y^{t}\right)=\frac{D_{0}^{t+1}\left(x^{t+1}, y^{t+1}\right)}{D_{0}^{t}\left(x^{t}, y^{t}\right)}\left[\frac{D_{0}^{t}\left(x^{t+1}, y^{t+1}\right)}{D_{0}^{t+1}\left(x^{t+1}, y^{t+1}\right)} \frac{D_{0}^{t}\left(x^{t}, y^{t}\right)}{D^{t+1}\left(x^{t}, y^{t}\right)}\right]^{1 / 2} .
$$

According to Ball et al. [2] output-based environmentally sensitive Malmquist productivity is defined as

$$
M_{E H}\left(x^{t+1}, y^{t+1}, b^{t+1}, x^{t}, y^{t}, b^{t}\right)=\frac{D_{0}^{t+1}\left(x^{t+1}, y^{t+1}, b^{t+1}\right)}{D_{0}^{t}\left(x^{t}, y^{t}, b^{t}\right)}\left[\frac{D_{0}^{t}\left(x^{t+1}, y^{t+1}, b^{t+1}\right)}{D_{0}^{t+1}\left(x^{t+1}, y^{t+1}, b^{t+1}\right)} \frac{D_{0}^{t}\left(x^{t}, y^{t}, b^{t}\right)}{D_{0}^{t+1}\left(x^{t}, y^{t}, b^{t}\right)}\right]^{1 / 2} \cdot
$$

Equation (2) can be decomposed into the environmental efficiency change out of the square brackets between the $t$ and $t+1$ periods and environmental technical progress, which is the geometric mean of the second term in the square brackets in the periods of $t$ and $t+1[3]$.

$$
E_{H}\left(x^{t+1}, y^{t+1}, b^{t+1}, x^{t}, y^{t}, b^{t}\right)=\frac{M_{E H}\left(x^{t+1}, y^{t+1}, b^{t+1}, x^{t}, y^{t}, b^{t}\right)}{M_{H}\left(x^{t+1}, y^{t+1}, x^{t}, y^{t}\right)} .
$$

$\mathrm{E}(\mathrm{H})$, the Malmquist environmental productivity index in Equation (3), is interpreted by the following three signs: if $\mathrm{E}(\mathrm{H})=1$, then it implies that environmental productivity growth and conventional productivity growth have no difference, that is, the pollution vector does not affect actual productivity growth; if $E(H)>1$, then it means that environmentally sensitive productivity growth is greater than conventional productivity growth. A change in environmental pollution has a positive impact on actual productivity growth, and; if $E(H)<1$, then environmentally sensitive productivity growth is less than conventional productivity growth. Actual productivity growth receives a negative impact from the change in environmental pollution [4].

\section{Data}

In this study, the authors used three proxies for inputs, two proxies for pollutants, and one proxy for output in the US air and truck transportation industries for the years of 2002, 2008, and 2011 ${ }^{1}$. The three inputs are number of establishments, number of workers, and fuel consumption used: thousand barrels of aviation gasoline and thousands barrels of motor gasoline for the air and truck transportation industries, respectively. Fuel consumption data were obtained from the State Energy Data System in the US Energy Information Administration [16], and the other two inputs were derived from the US Census Bureau (USCB) [17]. Unlike the truck transportation industry, the number of workers in the 25 states in the air transportation industry were recorded by using an average value between the minimum and maximum numbers of employees to protect the confidentiality of firms in the states: a state in the air transportation industry was recorded as having an average of 60 employees between 20 to 99 employees, 175 between 100 and 249 employees, and 375 between 250 and 499 employees.

As the two pollutants, $\mathrm{CO}$ and $\mathrm{PM}^{2}$ were chosen since they have been reported to cause harmful effects on humans and two indicators that states and planners measure and test alternatives against [18] [19]. To make the two air pollutants into air pollution inputs, the authors first collected National Emission Inventory data for the two pollutants measured in tons per year from the US Environmental Protection Agency [20], and then aggregated the levels of these two pollutants by state in each industry based on source classification codes (SSCs). However, the data for 2005 in the online database were partly missing and showed enormous measurement errors because some of the SSCs used for 2002, 2008, and 2011 were not present in the 2005 dataset and the aggregated levels of each pollutant by state in 2005 were shown to have extremely big outliers compared with those three years. Owing to a matter of bias and inconsistency, the authors only used the data from 2002, 2008, and 2011. For output, gross domestic product (GDP) in the air transportation industry was obtained from the US Bureau of Economic Analysis [21] and measured in millions of dollars.

\footnotetext{
${ }^{1}$ Air quality data were available in the years of 2002, 2005, 2008, and 2011, but data for the year of 2005 were partly missing and showed with large measurement errors.

${ }^{2}$ The US Environmental Protection Agency provides air quality data through National Emissions Inventory at the state level even though operating firms in a state span more than one state like motor carriers and airlines [20].
} 
Table 1 shows the average values of a state for the inputs, pollutants, and output in the two transportation industries in 2002, 2008, and 2011. Compared with the air transportation industry, the truck transportation industry produces much larger GDP, has a higher number of workers and establishments, and emits much more air pollution, which implies that this industry might have a more influential impact on productivity growth and air pollution reduction. In particular, CO and PM emissions in 2011 from the truck transportation industry were almost seven times and fifteen times larger than the emissions of the air transportation industry, respectively. However, overall the two transportation industries during the period show decrease in these two air pollutants from 2002 to 2011, excluding PM in the truck transportation industry, which decreased between 2008 and 2011.

\section{Discussion}

This study has some limitations. The number of workers in the 25 states in the air transportation industry was based on average values for confidentiality reasons; if original data about this were available to the public from the USCB, this study could have analyzed the conventional and environmentally sensitive Malmquist productivities and their efficiency and technological changes in the air transportation industry. In addition, the authors assumed that air pollution reductions have been affected by recent regulatory initiatives (the expansions of the Clean Air Act) [22] [23], but could not quantify the effect of this on environmental productivity growth as an input. The authors only suggested a couple of possible reasons such as the lack of preparedness for clean environmental constraints in the air transportation industry and much stricter air pollution prevention regulation in the truck transportation industry to explain the different air pollution levels from the two industries, but these might be two of many possible causes. A future study with a collection of more accurate data in air transportation industry might be performed later and then in addition to more transport sectors such as truck, vessel, pipeline, etc. the overall environmental analysis of air pollution by all transports will be able to be researched as using the Malmquist environmental productivity index.

\section{Empirical Results}

A Data Envelopment Analysis program 2.1 was used to calculate the Malmquist environmental productivity indexes in the air and truck transportation industries. The validity test for the conventional and environmentally sensitive Malmquist productivities in each industry was performed by using the nonparametric Wilcoxon Signed Ranks test. This test is generally used to compare whether two variables are identical to each other [24]-[26]. In Table 2, the conventional and environmentally sensitive Malmquist productivities were tested to assess if they are the same. The result shows that they are statistically significantly different from one another at $1 \%$ and $5 \%$ in the air and truck transportation industries, respectively.

Table 1. Average values by state for inputs, pollutants, and output for 2002, 2008, and 2011 in the air and truck transportation industries.

\begin{tabular}{|c|c|c|c|}
\hline Air transportation & 2002 & 2008 & 2011 \\
\hline GDP (millions of dollars) & 966 & 1240 & 1449 \\
\hline CO (tons) & 10,866 & 8500 & 8626 \\
\hline PM (tons) & 521 & 193 & 174 \\
\hline Number of establishments (ones) & 80 & 116 & 106 \\
\hline Number of workers (ones) & 2214 & 10,152 & 9498 \\
\hline Aviation gasoline used (thousands) & 131 & 112 & 111 \\
\hline Truck transportation & 2002 & 2008 & 2011 \\
\hline GDP (millions of dollars) & 1945 & 2449 & 2525 \\
\hline CO (tons) & 73,285 & 70,041 & 55,160 \\
\hline PM (tons) & 2324 & 3703 & 3092 \\
\hline Number of establishments (ones) & 2231 & 2287 & 2191 \\
\hline Number of workers (ones) & 28,660 & 28,389 & 26,512 \\
\hline Motor gasoline used (thousands) & 64,102 & 65,648 & 63,601 \\
\hline
\end{tabular}

Notes: data come from [16]-[21]. 
Table 2. Wilcoxon Signed Ranks test of the conventional and environmentally sensitive Malmquist productivities in the air and truck transportation industries.

\begin{tabular}{cc}
\hline Industry & Wilcoxon Signed Ranks Test \\
\hline Air Transportation & $-221.5(0.006)^{* * *}$ \\
Truck Transportation & $209.5(0.024)^{* *}$ \\
\hline
\end{tabular}

Notes: the null hypothesis of the Wilcoxon Signed Ranks test is that the mean difference between the conventional and environmentally sensitive Malmquist productivities is zero. ${ }^{* *}$ and ${ }^{* * *}$ indicate significance at $5 \%$ and $1 \%$, respectively.

For a state-level change, Table 3 and Table 4 show the average conventional and environmentally sensitive Malmquist productivities, their decompositions, and Malmquist environmental productivity indexes for 2002, 2008 and 2011 in the air and truck transportation industries. Table 5 explains the same results in terms of each industry.

In Table 3, on average, the Malmquist environmental productivity index by state for the air transportation industry is less than 1, (0.897), which implies that the change in air pollution averagely has a negative impact on actual productivity growth in a state. In fact, the air transportation industry does not generate actual productivity growth when considering that both air pollutants (CO and PM) decreased in 31 states and 40 states between 2002 and 2011, respectively. That is because the efforts to reduce air pollution might have a heavy burden on a decision-making unit against the productivity growth.

Many states in Table 3 show very high or low efficiency and technological changes in the conventional and environmentally sensitive Malmquist productivities, which is likely to be affected by the incorrect data used for the number of workers in 25 states due to confidentiality for firms. Thus, it is hard to make an exact inference about them from the result, but this finding can be used to interpret whether the air pollution reduction negatively or positively affects actual productivity growth since the same numbers of workers are still used to measure both conventional and environmental productivities.

Figure 1 provides a geographic map of the changes in the Malmquist environmental productivity index $(\mathrm{E}(\mathrm{H}))$ in a state from the increase in either CO, PM, or both for 2002-2011. The states showing an increase in each air pollutant or both with actual productivity growth are not desirable since this means productivity growth and pollution increase together; it is thus recommended to have more attention from state policymakers in those states and the administrator to reduce air pollutant(s). However, in the air transportation industry, the eight states of Arizona, New Hampshire, Oklahoma, Vermont, Connecticut, Delaware, Hawaii, and Kentucky show a trend of productivity growth and air pollution reduction.

The truck transportation industry shows that a change in air pollution had a positive impact on average actual productivity by state during the period, which is shown by an average Malmquist environmental productivity index greater than 1 (1.015 in Table 4). On average, the truck transportation industry in a state attained environmentally sustainable growth when considering actual productivity growth with decreases in these air pollutants: CO between 2002 (2008) and 2011 decreased in 31 (36) states and PM between 2002 (2008) and 2011 decreased in 4 (37) states. These air pollutants have been more strictly administered in the truck transportation industry since 2009 under section 202(a) of the Clean Air Act [5].

The efficiency and technological changes components in the conventional and environmentally sensitive Malmquist productivities can be hereafter further analyzed in the truck transportation industry unlike the air transportation industry. As Färe et al. [6] defined, efficiency change is interpreted as how much closer a state can access the ideal frontier, while technological change is defined by how much the ideal frontier shifts because of the existing technology. In Table 4, on average, conventional Malmquist productivity shows a positive productivity growth of $0.9 \%$ in a state, which is attributed to a very small efficiency decline, $0.001 \%$, and a technological growth of $0.9 \%$. This result implies that the truck transportation industry has marginally increased growth on average without decreasing air pollution, while environmentally sensitive Malmquist productivity shows a higher positive productivity growth of $2.4 \%$ in a state due to an decrease of $2.9 \%$ in efficiency change but an increase of $5.4 \%$ in technological change. This finding implies that actual productivity growth was positively affected by the decrease in air pollution.

The average efficiency score of environmentally sensitive Malmquist productivity is 0.971 for 2002, 2008, and 2011 (Table 4). This finding means that the decrease of $2.9 \%$ in air pollution in those three years can averagely increase actual productivity growth by the same percentage. Further, this reduction amount can reach 90,178 tons 
Table 3. Conventional and environmentally sensitive Malmquist productivities (M(H), M(EH)), their efficiency and technological changes (Effch and Techch), and the Malmquist environmental productivity index $\mathrm{E}(\mathrm{H})$ in the air transportation industry by state for $2002-2011$.

\begin{tabular}{|c|c|c|c|c|c|c|c|}
\hline State & Effch & Techch & $\mathbf{M}(\mathbf{H})$ & Effch & Techch & $\mathbf{M}(\mathbf{E H})$ & $\mathrm{E}(\mathrm{H})$ \\
\hline Alabama & 0.839 & 1.163 & 0.976 & 0.924 & 1.201 & 1.110 & 1.137 \\
\hline Alaska & 1.772 & 0.790 & 1.400 & 2.473 & 0.709 & 1.753 & 1.252 \\
\hline Arizona & 1.597 & 0.864 & 1.380 & 1.747 & 0.830 & 1.450 & 1.051 \\
\hline Arkansas & 3.522 & 0.658 & 2.317 & 3.342 & 0.682 & 2.278 & 0.983 \\
\hline California & 2.893 & 0.826 & 2.389 & 2.855 & 0.716 & 2.043 & 0.855 \\
\hline Colorado & 3.165 & 1.066 & 3.373 & 2.736 & 1.110 & 3.037 & 0.900 \\
\hline Connecticut & 1.226 & 0.813 & 0.997 & 1.235 & 0.810 & 1.000 & 1.003 \\
\hline Delaware & 1.309 & 0.698 & 0.914 & 1.307 & 0.714 & 0.933 & 1.021 \\
\hline District of Columbia & 1.193 & 0.781 & 0.931 & 1.181 & 0.784 & 0.926 & 0.995 \\
\hline Florida & 0.918 & 0.753 & 0.692 & 0.918 & 0.750 & 0.689 & 0.996 \\
\hline Georgia & 0.999 & 0.660 & 0.660 & 0.929 & 0.720 & 0.668 & 1.012 \\
\hline Hawaii & 0.605 & 0.737 & 0.446 & 0.656 & 0.741 & 0.486 & 1.090 \\
\hline Idaho & 1.324 & 0.809 & 1.071 & 1.324 & 0.809 & 1.071 & 1.000 \\
\hline Illinois & 1.216 & 0.778 & 0.946 & 1.179 & 0.783 & 0.923 & 0.976 \\
\hline Indiana & 1.248 & 0.786 & 0.981 & 1.179 & 0.735 & 0.867 & 0.884 \\
\hline Iowa & 1.276 & 0.687 & 0.877 & 1.199 & 0.656 & 0.787 & 0.897 \\
\hline Kansas & 1.325 & 0.716 & 0.948 & 1.298 & 0.732 & 0.950 & 1.002 \\
\hline Kentucky & 1.392 & 0.721 & 1.004 & 1.320 & 0.774 & 1.022 & 1.018 \\
\hline Louisiana & 1.332 & 0.636 & 0.848 & 1.392 & 0.629 & 0.876 & 1.033 \\
\hline Maine & 1.573 & 0.729 & 1.146 & 1.598 & 0.695 & 1.110 & 0.969 \\
\hline Maryland & 1.752 & 0.724 & 1.269 & 1.628 & 0.698 & 1.136 & 0.895 \\
\hline Massachusetts & 3.346 & 0.932 & 3.119 & 3.346 & 0.892 & 2.984 & 0.957 \\
\hline Michigan & 2.110 & 0.890 & 1.878 & 2.110 & 0.739 & 1.559 & 0.830 \\
\hline Mississippi & 2.214 & 0.825 & 1.826 & 2.205 & 0.644 & 1.420 & 0.778 \\
\hline Missouri & 0.614 & 0.945 & 0.580 & 0.288 & 0.414 & 0.119 & 0.205 \\
\hline Montana & 0.716 & 0.911 & 0.653 & 0.536 & 0.520 & 0.279 & 0.427 \\
\hline Nebraska & 0.536 & 1.036 & 0.555 & 0.389 & 0.616 & 0.239 & 0.431 \\
\hline Nevada & 0.449 & 0.805 & 0.362 & 0.428 & 0.811 & 0.347 & 0.959 \\
\hline New Hampshire & 0.419 & 0.740 & 0.310 & 0.410 & 0.797 & 0.327 & 1.055 \\
\hline New Jersey & 0.472 & 0.716 & 0.338 & 0.442 & 0.763 & 0.338 & 1.000 \\
\hline New Mexico & 0.537 & 0.740 & 0.398 & 0.630 & 0.619 & 0.390 & 0.980 \\
\hline New York & 0.564 & 0.740 & 0.418 & 0.602 & 0.654 & 0.394 & 0.943 \\
\hline North Carolina & 0.559 & 0.673 & 0.376 & 0.559 & 0.677 & 0.379 & 1.008 \\
\hline North Dakota & 1.000 & 0.772 & 0.772 & 1.000 & 0.791 & 0.791 & 1.025 \\
\hline Ohio & 1.162 & 0.869 & 1.010 & 1.156 & 0.789 & 0.912 & 0.903 \\
\hline Oklahoma & 0.989 & 0.770 & 0.762 & 1.083 & 0.775 & 0.839 & 1.101 \\
\hline Oregon & 5.344 & 0.781 & 4.174 & 5.087 & 0.753 & 3.831 & 0.918 \\
\hline Pennsylvania & 3.655 & 0.638 & 2.332 & 3.498 & 0.636 & 2.226 & 0.955 \\
\hline South Carolina & 4.380 & 0.643 & 2.818 & 4.046 & 0.648 & 2.622 & 0.930 \\
\hline South Dakota & 0.364 & 0.728 & 0.265 & 0.297 & 0.446 & 0.132 & 0.498 \\
\hline Tennessee & 0.374 & 0.786 & 0.294 & 0.381 & 0.777 & 0.296 & 1.007 \\
\hline Texas & 0.406 & 0.869 & 0.353 & 0.409 & 0.832 & 0.341 & 0.966 \\
\hline Utah & 1.913 & 0.797 & 1.524 & 1.910 & 0.738 & 1.410 & 0.925 \\
\hline Vermont & 1.948 & 0.729 & 1.421 & 2.212 & 0.730 & 1.615 & 1.137 \\
\hline Virginia & 2.314 & 0.691 & 1.600 & 2.089 & 0.692 & 1.447 & 0.904 \\
\hline Average & 1.200 & 0.780 & 0.936 & 1.162 & 0.723 & 0.840 & 0.897 \\
\hline
\end{tabular}

Notes: air transportation information for Minnesota, Rhode Island, Washington, West Virginia, Wisconsin, and Wyoming is not available in the USCB online database, and thus 45 states are used for this productivity analysis. 
Table 4. Conventional and environmentally sensitive Malmquist productivities (M(H), M(EH)), their efficiency and technological changes (Effch and Techch), and the Malmquist environmental productivity index $\mathrm{E}(\mathrm{H})$ in the truck transportation industry by state for 2002-2011.

\begin{tabular}{|c|c|c|c|c|c|c|c|}
\hline State & Effch & Techch & $\mathbf{M}(\mathbf{H})$ & Effch & Techch & M(EH) & $\mathbf{E}(\mathrm{H})$ \\
\hline Alabama & 1.207 & 1.022 & 1.234 & 1.125 & 1.088 & 1.224 & 0.992 \\
\hline Alaska & 1.115 & 1.039 & 1.158 & 1.076 & 1.059 & 1.139 & 0.984 \\
\hline Arizona & 0.861 & 1.015 & 0.874 & 0.896 & 1.027 & 0.921 & 1.054 \\
\hline Arkansas & 1.050 & 1.013 & 1.064 & 0.955 & 1.074 & 1.026 & 0.964 \\
\hline California & 0.899 & 0.999 & 0.898 & 0.869 & 1.056 & 0.918 & 1.022 \\
\hline Colorado & 0.759 & 0.987 & 0.749 & 0.771 & 1.021 & 0.787 & 1.051 \\
\hline Connecticut & 1.144 & 0.945 & 1.081 & 1.144 & 0.980 & 1.121 & 1.037 \\
\hline Delaware & 1.046 & 0.960 & 1.004 & 1.043 & 1.019 & 1.063 & 1.059 \\
\hline District of Columbia & 0.755 & 0.983 & 0.742 & 0.761 & 1.032 & 0.785 & 1.058 \\
\hline Florida & 0.924 & 0.983 & 0.909 & 0.806 & 1.076 & 0.867 & 0.954 \\
\hline Georgia & 1.043 & 0.998 & 1.041 & 1.000 & 1.074 & 1.075 & 1.033 \\
\hline Hawaii & 0.825 & 0.969 & 0.800 & 0.874 & 0.979 & 0.856 & 1.070 \\
\hline Idaho & 1.114 & 1.013 & 1.129 & 1.104 & 1.054 & 1.163 & 1.030 \\
\hline Illinois & 1.056 & 0.989 & 1.044 & 1.013 & 1.089 & 1.103 & 1.057 \\
\hline Indiana & 0.782 & 0.966 & 0.755 & 0.740 & 1.026 & 0.759 & 1.005 \\
\hline Iowa & 1.146 & 0.959 & 1.099 & 1.067 & 1.019 & 1.088 & 0.990 \\
\hline Kansas & 1.106 & 0.959 & 1.061 & 1.025 & 1.034 & 1.060 & 0.999 \\
\hline Kentucky & 0.871 & 0.969 & 0.844 & 0.824 & 1.026 & 0.845 & 1.001 \\
\hline Louisiana & 1.065 & 0.960 & 1.022 & 0.957 & 1.040 & 0.996 & 0.975 \\
\hline Maine & 1.048 & 0.965 & 1.011 & 1.010 & 1.003 & 1.013 & 1.002 \\
\hline Maryland & 0.890 & 0.994 & 0.885 & 0.907 & 1.000 & 0.907 & 1.025 \\
\hline Massachusetts & 1.156 & 0.991 & 1.145 & 1.070 & 1.056 & 1.130 & 0.987 \\
\hline Michigan & 1.373 & 0.985 & 1.352 & 1.260 & 1.076 & 1.356 & 1.003 \\
\hline Minnesota & 0.992 & 0.988 & 0.980 & 1.272 & 0.993 & 1.262 & 1.288 \\
\hline Mississippi & 1.215 & 0.969 & 1.178 & 1.216 & 1.023 & 1.244 & 1.056 \\
\hline Missouri & 0.990 & 1.003 & 0.993 & 0.991 & 1.049 & 1.039 & 1.046 \\
\hline Montana & 0.814 & 0.995 & 0.811 & 0.817 & 1.048 & 0.856 & 1.055 \\
\hline Nebraska & 1.212 & 0.975 & 1.181 & 1.180 & 1.032 & 1.218 & 1.031 \\
\hline Nevada & 1.117 & 1.020 & 1.140 & 1.080 & 1.061 & 1.146 & 1.005 \\
\hline New Hampshire & 0.907 & 1.019 & 0.924 & 0.868 & 1.070 & 0.929 & 1.005 \\
\hline New Jersey & 1.117 & 0.995 & 1.111 & 1.107 & 1.012 & 1.120 & 1.008 \\
\hline New Mexico & 1.050 & 1.035 & 1.087 & 1.044 & 1.072 & 1.120 & 1.030 \\
\hline New York & 1.001 & 1.109 & 1.110 & 1.015 & 1.107 & 1.124 & 1.013 \\
\hline North Carolina & 1.282 & 1.107 & 1.419 & 1.268 & 1.131 & 1.435 & 1.011 \\
\hline North Dakota & 1.171 & 1.179 & 1.381 & 1.156 & 1.199 & 1.385 & 1.003 \\
\hline Ohio & 0.881 & 1.051 & 0.926 & 0.809 & 1.096 & 0.887 & 0.958 \\
\hline Oklahoma & 1.151 & 1.109 & 1.277 & 1.089 & 1.163 & 1.266 & 0.991 \\
\hline Oregon & 1.127 & 1.042 & 1.175 & 1.000 & 0.943 & 0.943 & 0.803 \\
\hline Pennsylvania & 0.814 & 1.057 & 0.860 & 0.934 & 1.039 & 0.971 & 1.129 \\
\hline Rhode Island & 1.059 & 1.011 & 1.070 & 0.950 & 1.073 & 1.019 & 0.952 \\
\hline South Carolina & 0.919 & 1.039 & 0.955 & 0.901 & 1.079 & 0.973 & 1.019 \\
\hline South Dakota & 0.764 & 1.067 & 0.814 & 0.747 & 1.100 & 0.822 & 1.010 \\
\hline Tennessee & 1.061 & 1.019 & 1.081 & 0.967 & 1.084 & 1.048 & 0.969 \\
\hline Texas & 0.954 & 1.003 & 0.956 & 0.942 & 1.098 & 1.034 & 1.082 \\
\hline Utah & 0.719 & 0.973 & 0.700 & 0.713 & 1.021 & 0.728 & 1.040 \\
\hline Vermont & 1.008 & 1.036 & 1.045 & 0.867 & 1.154 & 1.001 & 0.958 \\
\hline Virginia & 0.956 & 1.020 & 0.974 & 0.894 & 1.051 & 0.940 & 0.965 \\
\hline Average & 0.999 & 1.009 & 1.009 & 0.971 & 1.054 & 1.024 & 1.015 \\
\hline
\end{tabular}

Notes: truck transportation information for Washington, West Virginia, Wisconsin, and Wyoming is not available in the USCB online database, and thus 47 states are used for this productivity analysis. 
Table 5. Conventional and environmentally sensitive Malmquist productivities (M(H), M(EH)), their efficiency and technological changes (Effch and Techch), and the Malmquist environmental productivity Index $\mathrm{E}(\mathrm{H})$ in the air and truck transportation industries for 2008 and 2011.

\begin{tabular}{ccccccccc}
\hline Air Transportation & Effch & Techch & $\mathbf{M}(\mathbf{H})$ & Effch & Techch & $\mathbf{M ( E H )}$ & $\mathbf{E}(\mathbf{H})$ \\
\hline 2008 & 1.019 & 0.628 & 0.640 & 1.089 & 0.512 & 0.557 & 0.870 \\
2011 & 1.413 & 0.969 & 1.370 & 1.240 & 1.021 & 1.265 & 0.923 \\
\hline Truck Transportation & Effch & Techch & $\mathbf{M}(\mathbf{H})$ & $\mathbf{E f f c h}$ & Techch & $\mathbf{M}(\mathbf{E H})$ & $\mathbf{E ( H )}$ \\
\hline 2008 & 1.076 & 0.893 & 0.961 & 1.022 & 0.963 & 0.984 & 1.023 \\
2011 & 0.928 & 1.141 & 1.009 & 0.922 & 1.154 & 1.065 & 1.055 \\
\hline
\end{tabular}

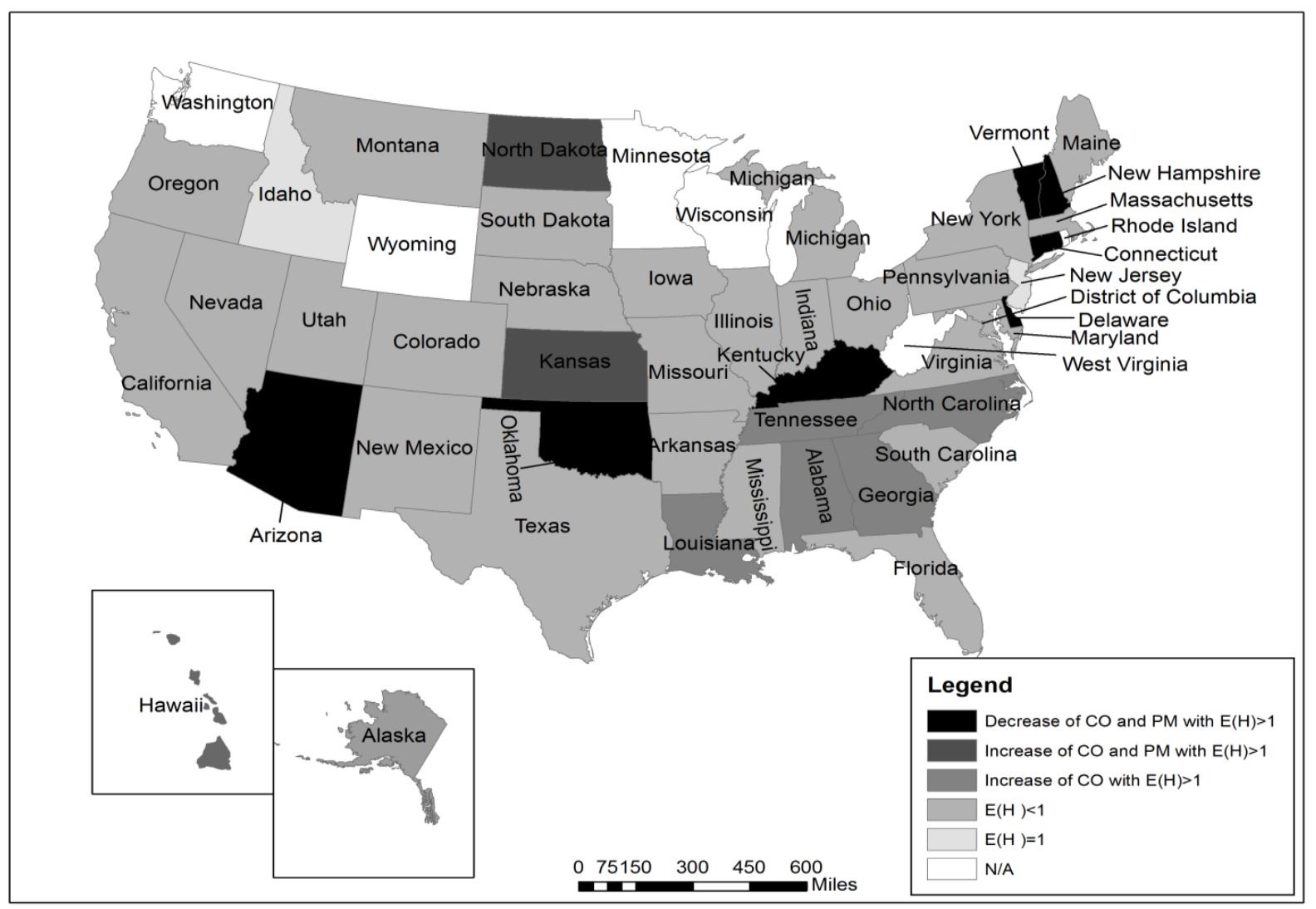

Figure 1. Geographic map of the changes in the Malmquist environmental productivity index $\mathrm{E}(\mathrm{H})$ in a state from the increase in either CO, PM, or both in the air transportation industry for 2002-2011.

of CO and 4,142 tons of PM for the average three-year period. The possible reduction amount in CO and PM reaches half and one-third of emissions in the largest air polluting state, California, respectively.

In Figure 2, a geographic map is provided of the changes in the Malmquist environmental productivity index $(\mathrm{E}(\mathrm{H}))$ in a state from the increase in either CO, PM, or both for 2002-2011. The 16 states in Figure 2 show increases in PM and $\mathrm{E}_{\mathrm{H}}$, but only three states (Mississippi, South Carolina, and Utah) continue to increase PM for the consecutive years of 2002, 2008, and 2011. The rest of the states initially increase emitting the pollutant, but after 2008, this amount declines. The following 12 states that show an increase in both pollutants with $\mathrm{E}(\mathrm{H})>1$ are recommended to be focused on since they are swimming against the tide of productivity growth and air pollution reduction in the truck transportation industry: Delaware, District of Columbia, Idaho, Maryland, Missouri, Montana, Nevada, New Jersey, North Carolina, North Dakota, Pennsylvania, and South Dakota.

Table 5 summarizes the annual average conventional and environmentally sensitive Malmquist productivities, the Malmquist environmental productivity index, and their components for the air and truck transportation industries in 2008 and 2011. In the air transportation industry, although actual productivity growth in 2011 decreased 


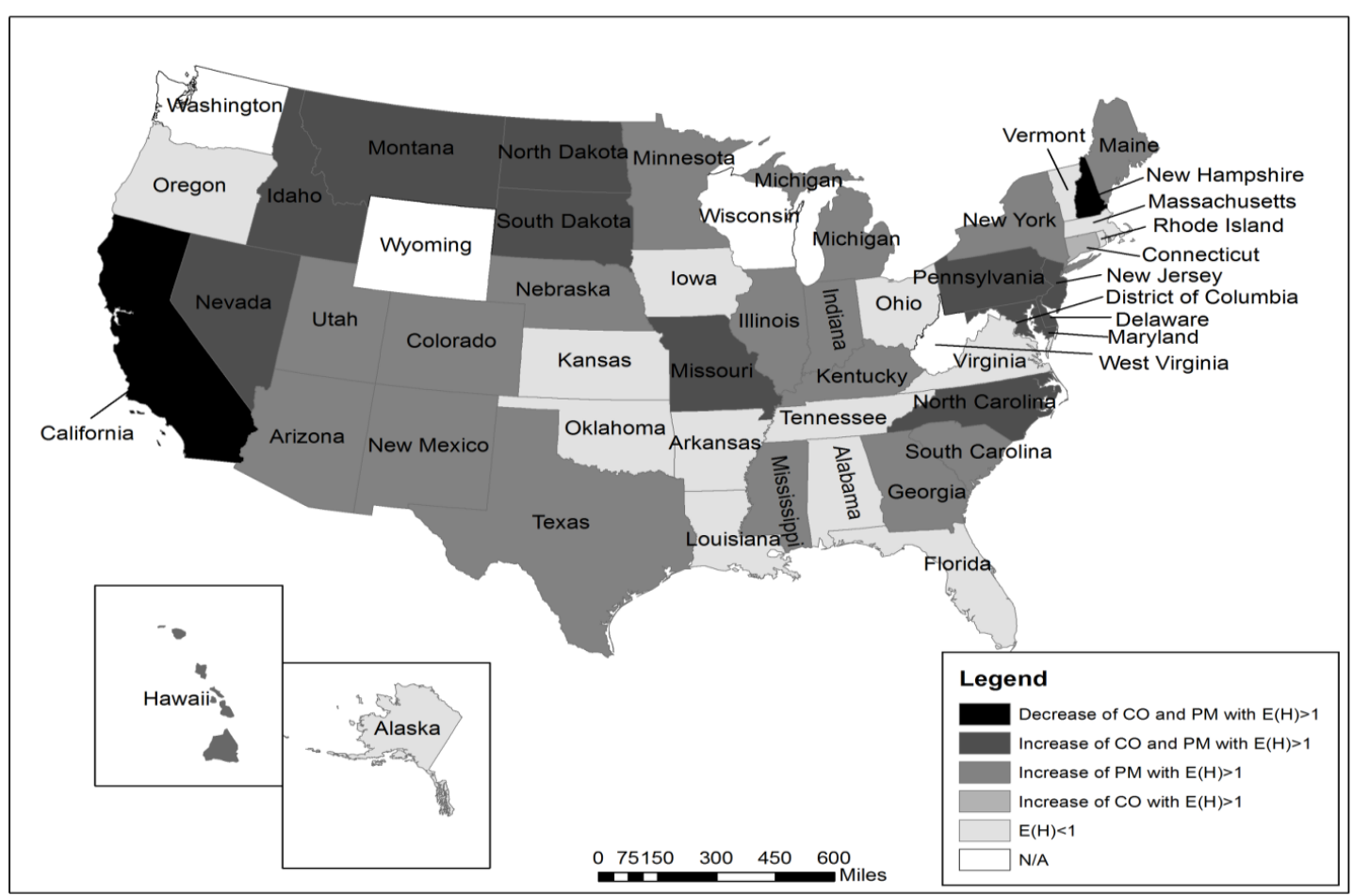

Figure 2. Geographic map of the changes in the Malmquist environmental productivity index $\mathrm{E}(\mathrm{H})$ in a state from the increase in either CO, PM, or both in the truck transportation industry for 2002-2011.

less with the air pollution reduction than that for 2008 (Malmquist environmental productivity indexes in 2008 and 2011), it is not still close to the ideal frontier, 1 . On the other hand, the truck transportation industry passes its ideal frontier with actual productivity growth from the decrease in air pollution in 2008 and 2011.

\section{Conclusions}

Air pollution worsens the work environment and increases the likelihood of health risks and even premature death for humans. Owing to the fundamental structure of growth through the combustion of fossil fuels, productivity growth in the transportation industry damages the natural environment. However, a change from transportation for people to transportation for people and the environment is happening around the world through the development of environmentally friendly transport modes and the proliferation of eco-friendly laws. In this study, the biggest air polluters, the air and truck transportation industries in the US, were practically investigated in order to reveal whether both transportation industries are approaching environmentally sustainable growth and alert the states showing actual productivity growth and air pollution increases.

Our major findings are as follows: 1) on average, the air transportation industry in a state was not ready to become an environmentally sustainable transportation industry, but the truck transportation industry positively grew with reductions in one of the pollutants or both. This finding might be explained by the new stricter air pollution regulations and improvement in fuel efficiency in the truck transportation industry at the end of the 2000s; and 2) the two states of Kansas and North Dakota in the air transportation industry and the 12 states of Delaware, District of Columbia, Idaho, Maryland, Missouri, Montana, Nevada, New Jersey, North Carolina, North Dakota, Pennsylvania, and South Dakota in the truck transportation industry showed a rise in air pollution with productivity growth. Thus, special attention is recommended to reduce air pollutants while increasing actual productivity growth in those states.

\section{Acknowledgements}

This research was supported by Mountain-Plains Consortium, which is sponsored by the US Department of Transportation through its university Transportation Centers Program. The contents are sole responsibility of the authors. The authors also would like to thank anonymous reviewers for their constructive comments. 


\section{References}

[1] Rodrigue, J.P. and Notteboom, T. (2013) The Geography of Transport Systems.

[2] The World Health Organization (2002) The World Health Report 2002-Reducing Risks, Promoting Healthy Life. http://www.who.int/whr/2002/chapter4/en/index7.html.

[3] The World Health Organization (2012) Burden of Disease from Household Air Pollution for 2012. http://www.who.int/phe/health topics/outdoorair/databases/FINAL HAP AAP BoD 24March2014.pdf?ua=1.

[4] The US Environmental Protection Agency (2011) The Benefits and Costs of the Clean Air Act from 1990 to 2020. http://www.epa.gov/cleanairactbenefits/feb11/fullreport_rev_a.pdf.

[5] Färe, R., Grosskopf, S., Lindgren, B. and Roos, P. (1992) Productivity Changes in Swedish Pharamacies 1980-1989: A Non-Parametic Malmquist Approach. The Journal of Productivity Analysis, 3, 85-101. http://dx.doi.org/10.1007/BF00158770

[6] Färe, R., Grosskopf, S., Norris, M. and Zhang, Z. (1994A) Productivity Growth, Technical Progress, and Efficiency Change in Industrialized Countries. The American Economic Review, 1, 66-83.

[7] Färe, R., Grosskopf, S., Lindgren, B. and Roos, P. (1994B) Data Envelopment Analysis: Theory, Methodology, and Application. Kluwer Academic Publishers, Boston.

[8] Färe, R. and Grosskopf, S. (1994) Theory and Calculation of Productivity Indexes. Models and Measurement of Welfare and Inequality, 921-940.

[9] Meyer, J.R. and Gomez-Ibanez, J.A. (1980) Measurement and Analysis of Productivity in Transportation Industries. New Developments in Productivity Measurement, 293-332.

[10] Gordon, R.J. (1992) Productivity in the Transportation Sector in Output Measurement in the Service Sectors. University of Chicago Press, Chicago.

[11] Ball, V.E., Lovell, C.A.K., Luu, H. and Nehring, R. (2004) Incorporating Environmental Impacts in the Measurement of Agricultural Productivity Growth. Journal of Agricultural and Resource Economics, 3, 436-460.

[12] Managi, S., Opaluch, J.J., Jin, D. and Grigalunas, T.A. (2005) Environmental Regulations and Technological Change in the Offshore Oil and Gas Industry. Land Economics, 81, 303-319.

[13] Managi, S. (2006) Are There Increasing Returns to Pollution Abatement? Empirical Analytics of the Environmental Kuznets Curve in Pesticides. Ecological Economics, 58, 617-636. http://dx.doi.org/10.1016/j.ecolecon.2005.08.011

[14] Emilio, G.G. (2010) Exporting and Environmental Performance: A Firm-Level Productivity Analysis. The World Economy, 33, 60-88.

[15] Heng, Y., Lim, S.H. and Chi, J. (2012) Toxic Air Pollutants and Trucking Productivity in the US. Transportation Research Part D: Transport and Environment, 17, 309-316. http://dx.doi.org/10.1016/j.trd.2012.01.001

[16] The US Energy Information Administration (2014) The State Energy Data System. http://www.eia.gov/state/seds/

[17] The US Census Bureau (2014) American Fact Finder. http://factfinder.census.gov/faces/nav/jsf/pages/index.xhtml

[18] Chang, T., Zivin, J.S.G., Gross, T. and Neidell, M.J. (2014) Particulate Pollution and the Productivity of Pear Packers. National Bureau of Economic Research, Cambridge. http://dx.doi.org/10.3386/w19944

[19] The United States Environmental Protection Agency (2014) Carbon Monoxide. http://www.epa.gov/airquality/carbonmonoxide/health.html

[20] The US Environmental Protection Agency (2014) Emission Inventories. http://www.epa.gov/ttn/chief/eiinformation.html

[21] The US Bureau of Economic Analysis (2014) Interactive Data. http://www.bea.gov/itable/index.cfm

[22] The US Environmental Protection Agency (2014) Clean Air Act. http://www.epa.gov/air/caa/title2.html

[23] Choi, J., Roberts, D.C. and Lee, E. (2014) Forecast of $\mathrm{CO}_{2}$ Emissions from the US Transportation Sector: Estimation from a Double Exponential Smoothing Model. Journal of the Transportation Research Forum, 53, 63-82.

[24] The SAS Institute Incorporation (2014) Base SAS(R) 9.2 Procedures Guide: Statistical Procedures. http://support.sas.com/documentation/cdl/en/procstat/63104/HTML/default/viewer.htm\#procstat_univariate_sect029.ht $\underline{\mathrm{m}}$

[25] Choi, J., Roberts, D.C. and Lee, E. (2015) Productivity Growth in the Transportation Industries in the United States: An Application of the DEA Malmquist Productivity Index. American Journal of Operations Research, 5, 1-20. http://dx.doi.org/10.4236/ajor.2015.51001

[26] Choi, J. and Roberts, D.C. (2015) How Does a Carbon Dioxide Emission Change Affect Transportation Productivity? A Case Study of the US Transportation Sector from 2002 to 2011. 
Scientific Research Publishing (SCIRP) is one of the largest Open Access journal publishers. It is currently publishing more than 200 open access, online, peer-reviewed journals covering a wide range of academic disciplines. SCIRP serves the worldwide academic communities and contributes to the progress and application of science with its publication.

Other selected journals from SCIRP are listed as below. Submit your manuscript to us via either submit@scirp.org or Online Submission Portal.
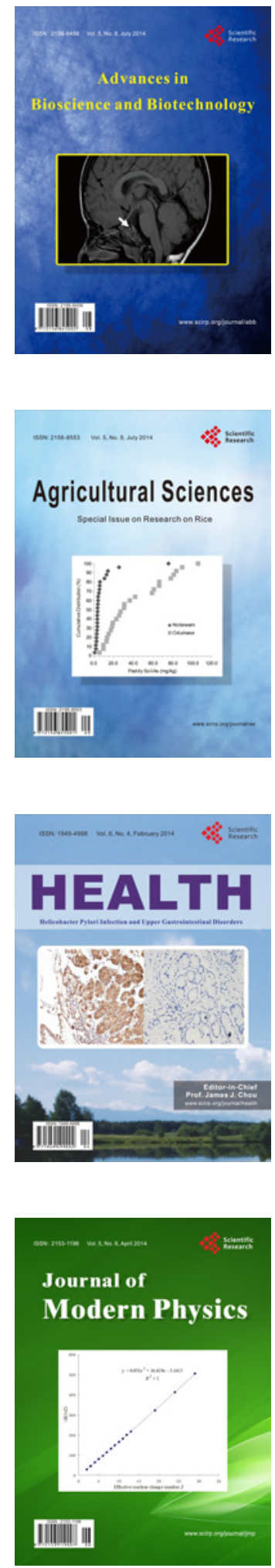
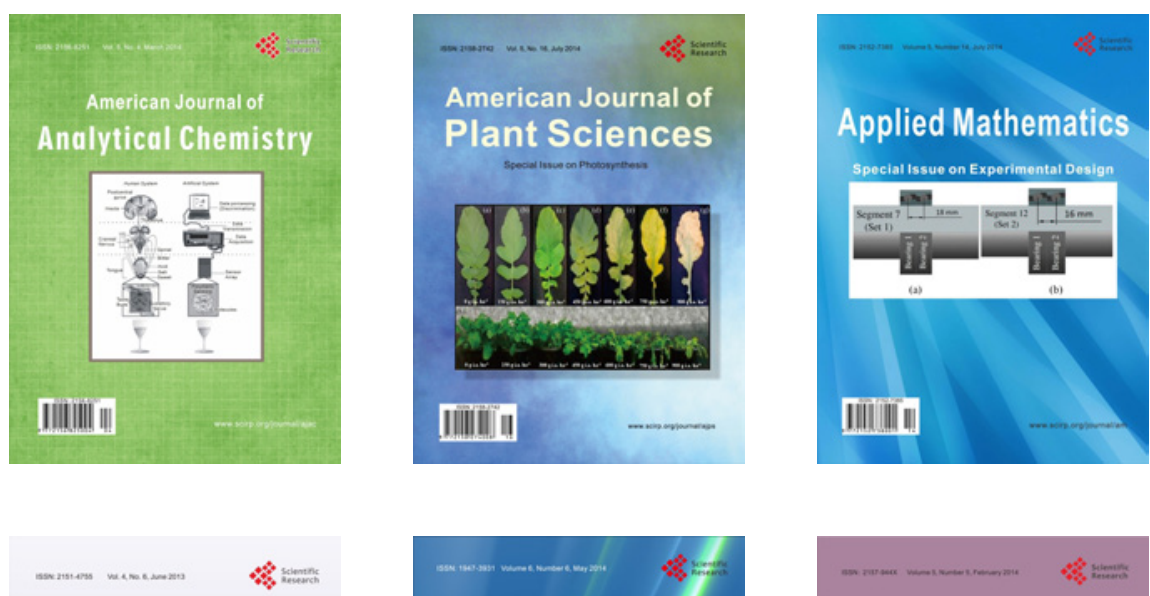

Creative Education
